\title{
Hydrodynamic screws as an alternative for small hydropower generation in Colombia
}

\author{
M. E. Madrid, J. M. Toro \& S. Ortega \\ Escuela de Ingeniería de Antioquia, Colombia
}

\begin{abstract}
Hydrodynamic screws could be an interesting alternative for low-head hydropower generation in Colombia, due to the simplicity of their use in civil works and their reduced environmental impact. This study aims to determine the technical and economic feasibility of hydrodynamic screws for power generation in Colombia, taking El Chuscal Creek (located in eastern Antioquia) as a case study. The site selected for the designs and analysis is representative of the Colombian mountain topography. In order to determine the technical feasibility, parameters such as geometrical design, site topography and hydrology are characterized. The economic viability considers the cost of the screw and the generator, the civil works and the maintenance required. A financial flow is constructed to conceptually evaluate the project. These projects could be implemented in the country with small environmental impacts, as there is very small alteration of sediment dynamics. In the current market and considering regulatory conditions, it is unlikely that these projects are feasible for grid generation, but they could be an interesting alternative for self-consumption. Changes in regulatory conditions and technological advancements (like smart grids) could make these projects competitive.
\end{abstract}

Keywords: hydrodynamic screw, small-hydropower.

\section{Introduction}

Colombia has an abundant water generation potential, $64,1 \%$ of the generation is based on hydropower and $30,8 \%$ on fossil fuels, for a total installed capacity of 13.279 MW [1]. The electric market involves both public and private capital. Private investment has been very significant in the last decade with numerous power plants with installed output of less than $100 \mathrm{MW}$ [2]. 
The structure of the Colombian electrical generation market, with such a considerable hydro participation, represents a strong barrier for non-conventional energy production technologies, mainly because of low energy prices. Moreover, considerable hydropower potential is still available: a total power output of around 23.947 MW has been estimated for Antioquia (Colombia's most hydroelectrically exploited region) alone [2].

Despite this, large-hydro comes with a series of adverse environmental impacts, such as sediment catchments, fish transit, valuable land flooding, and displacement of human settlements. Hydrodynamic screws seem to be an interesting technology for Colombia considering that it is a non-conventional energy technology, which takes advantage of the vast hydraulic sources in a smaller scale, avoiding these environmental problems. For instance, fish friendliness of the screws has been proved [3], there is no significant flooding and the pass of sediments is not interrupted.

On the other side, simplicity of civil works for the installation of hydrodynamic screws for power generation would attract local engineering companies for both design and construction phases.

Broad expansion of hydrodynamic screw has been seen in Europe during the last years, with more than 180 generation spots built [4]. No evidence of this type of project has been found in Colombia by the authors of this document. An example of a built site is displayed in Figure 1.

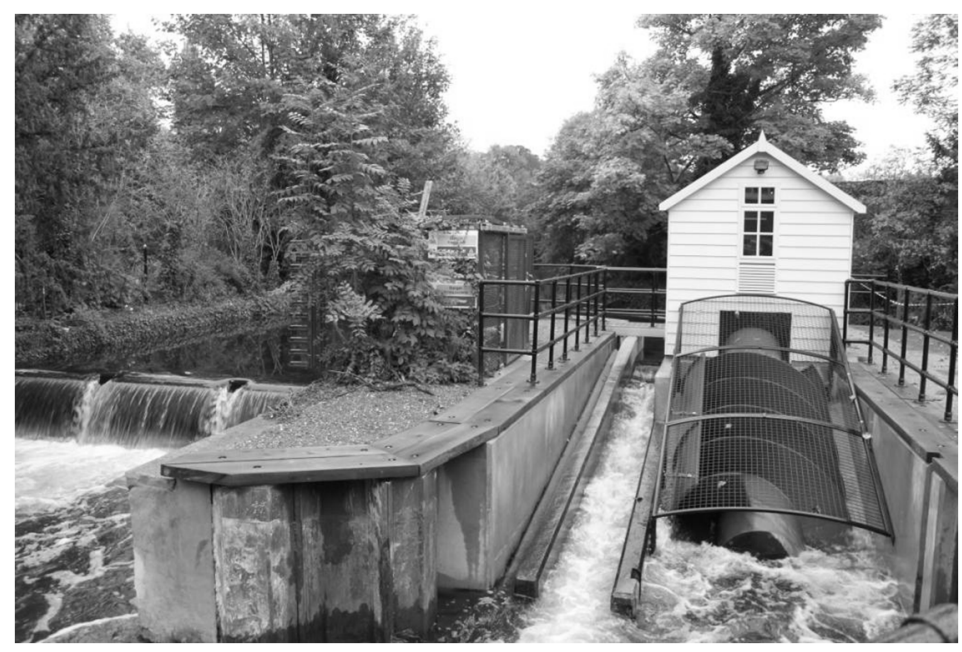

Figure 1: Hydrodynamic screw, Morden Hall Park, England (National Trust).

\section{Site description}

El Chuscal Creek is located in the Municipality of El Retiro in Antioquia, Colombia, $30 \mathrm{~km}$ away from Medellín. The project will be located at an altitude of $2.175 \mathrm{~m}$, creating a basin of $18 \mathrm{~km}^{2}$, the mean precipitation in the area is 
$2.200 \mathrm{~mm} /$ year. El Chuscal Creek has a length of $2.7 \mathrm{~km}$ before flowing into the Pantanillo River.

El Chuscal Creek basin is relatively small and may be schematically divided into an upper and shallow part and a lower and steeper zone in which the project may be located, where $2 \mathrm{~m}$ cascades are frequent in rock formations. So, a site with a $2.80 \mathrm{~m}$ head potential is selected in a curved stretch. The site represents the conditions of typical Colombian mountain terrain, and it is shown in Figure 2.

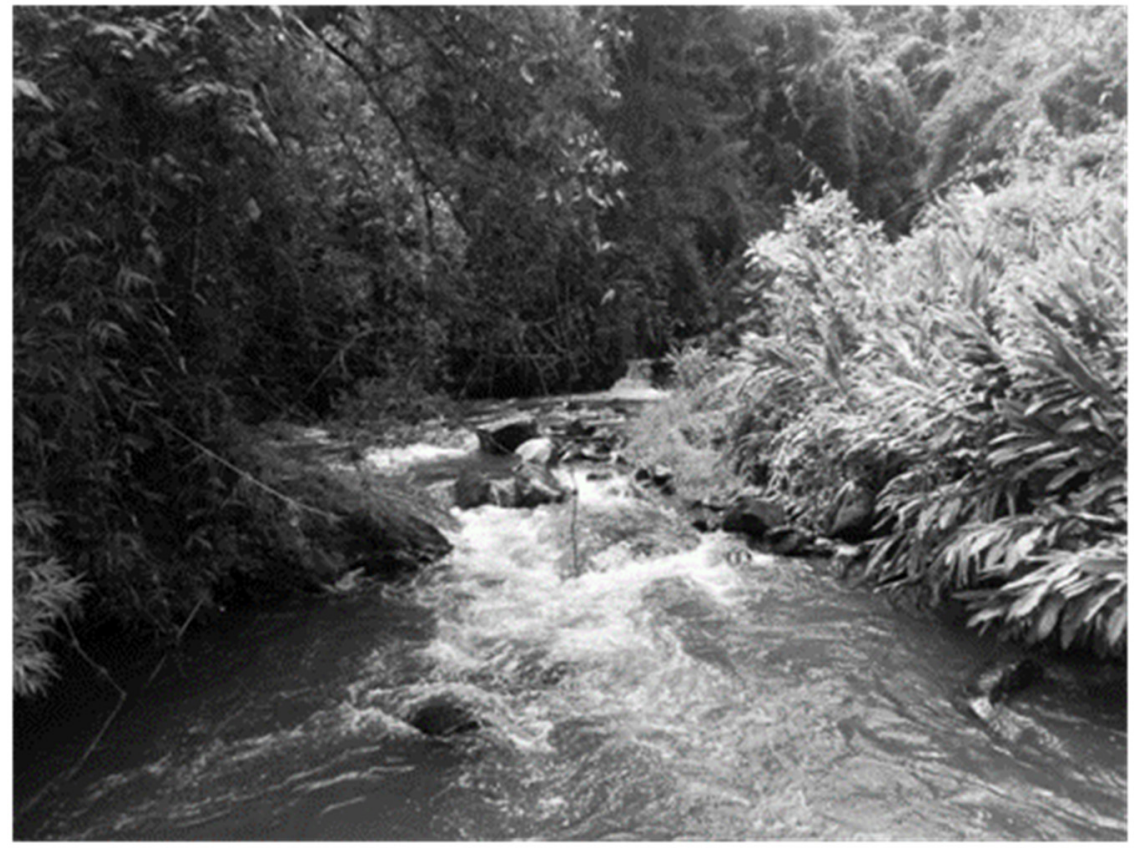

Figure 2: $\quad$ Project site.

Using a digital elevation model from Hidrosig (Hidrology software developed by Universidad Nacional de Colombia) the basin for El Chuscal Creek is determined for the project site selected.

Figure 3 shows the basin associated with the project site. Two more basins are shown and they correspond to the closest flow measurement stations on the Pantanillo River: Montenevado and Guarango. Daily flow registrations were available for both of them; nevertheless just the information from Guarango station is used for calculations because of closest topography and basin size similarity to El Chuscal Creek basin.

\subsection{Flow duration curve}

Flow data for El Chuscal Creek are not available since any flow measurement stations exist. Even though, a synthetic flow curve may be generated under the 


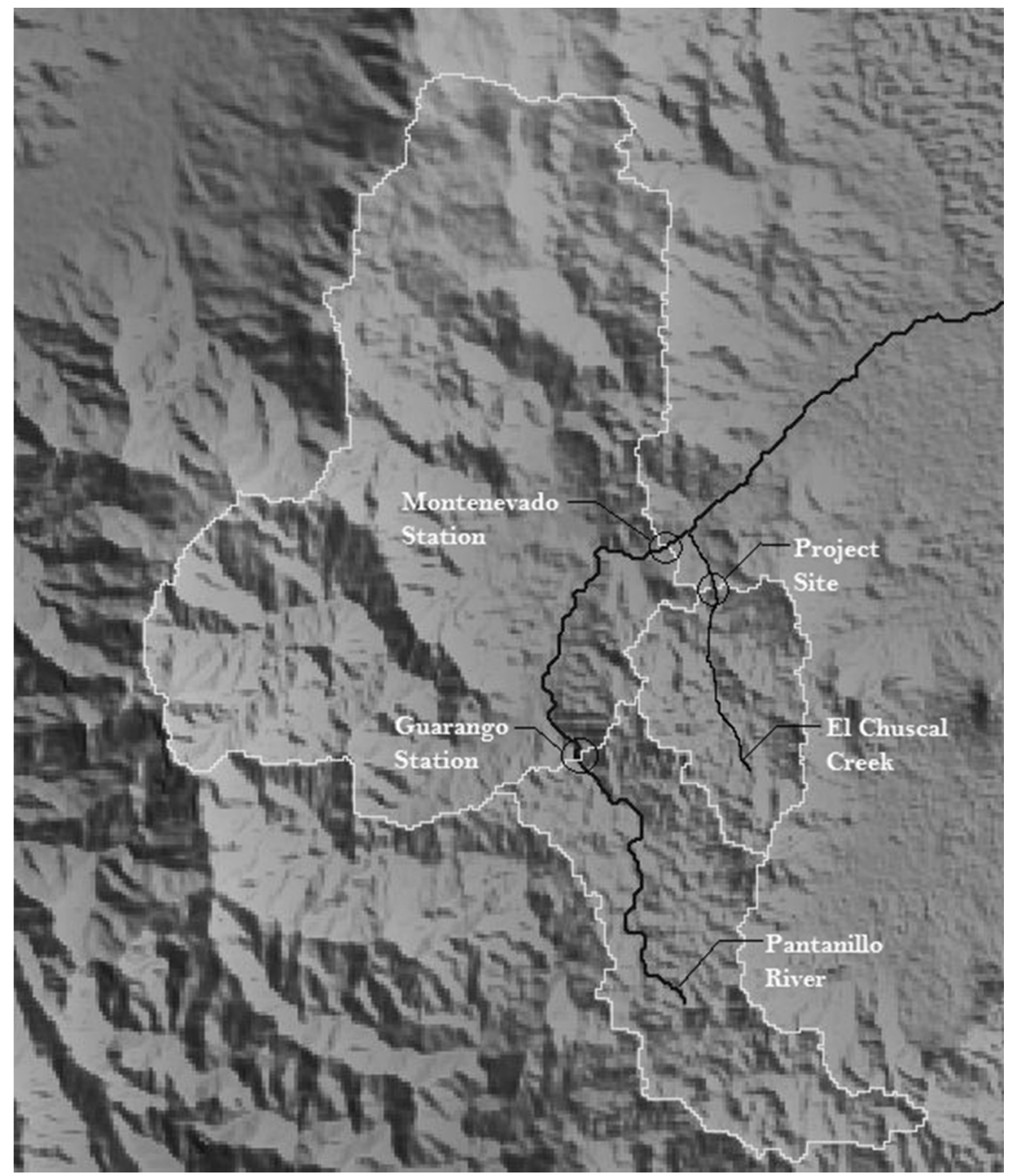

Figure 3: Project site basin (El Chuscal) and closest flow measurements stations and basins (Montenevado, Guarango).

assumption of a direct relation between the mean flow of the two water currents, Pantanillo River and El Chuscal Creek, using the data of the Guarango flow measuring station. There are 9.1 years of data at a daily resolution. The generated series is presented below in Figure 4.

Then, a flow synthetic duration curve may be constructed for both Pantanillo River and El Chuscal Creek: 


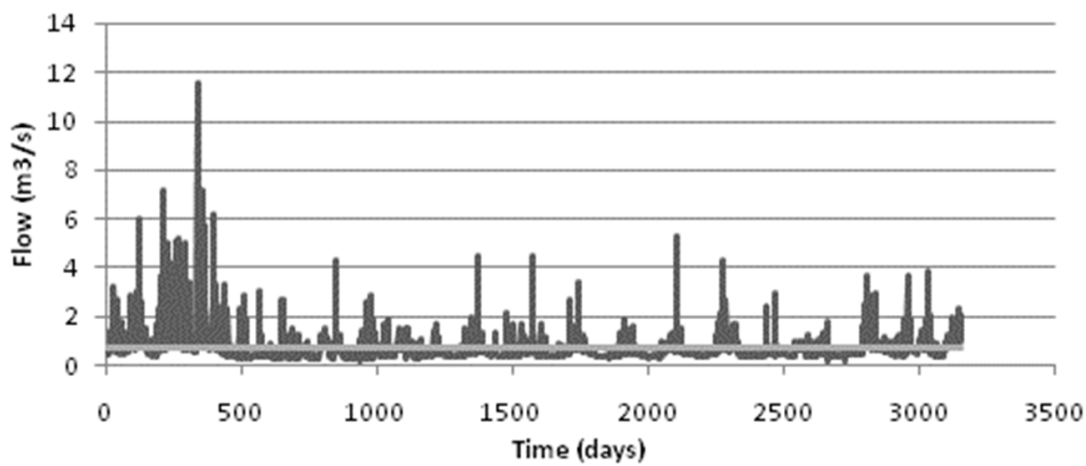

Figure 4: El Chuscal flow synthetic series.

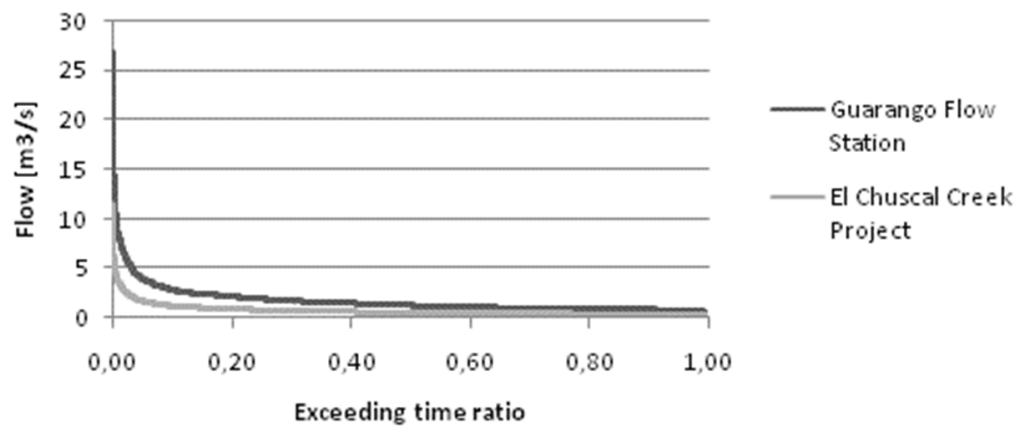

Figure 5: Synthetic flow duration curve.

The main purpose of this curve is to determine the flow for which the project may be designed. In this case, a flow that may be available $95 \%$ of the time is selected: $0,775 \mathrm{~m}^{3} / \mathrm{s}$. On August 12 $2^{\text {th }}, 2013$, a direct measurement of the flow was also carried to verify the assumption on secondary sources. A flow of $0,718 \mathrm{~m}^{3} / \mathrm{s}$ was found. Finally a $0.810 \mathrm{~m}^{3} / \mathrm{s}$ is stated as mean value for El Chuscal Creek in local bibliography [5].

With this information, a flow of $0.775 \mathrm{~m}^{3} / \mathrm{s}$ was considered as mean flow. The design flow is calculated with the mean flow, reduced by the ecological flow calculated as the flow present $75 \%$ of the time, in this case study $\mathrm{Q}_{\text {ecologic }}=0.168$ $\mathrm{m}^{3} / \mathrm{s}$. Then the power generating flow was $0.607 \mathrm{~m}^{3} / \mathrm{s}$.

\section{Design of the screw}

The geometry of this moving piece governs the efficiency of the machine. The philosophy of maximization is transporting the maximum amount of water with a 
single turn of the axis. Several variables may be chosen: inner radius, outer radius, relation between radiuses. This last ratio was found as optimal when it has a value of 0.54 [6].

The number of flights of the screw is susceptible of optimization: the volume per turn ratio increases continuously as the number of flights is increased [6]. Even though, welding process of screws with a large amount of spiral blades or starts results impractical, reason why 3 flights designs are preferred.

Inclination of the screw axis is an important variable to be chosen, since the volume of the water buckets formed between successive blades depends on it. The value leading to an optimal value corresponds to a $3 \mathrm{H}: 8 \mathrm{~V}$ relation [6], equivalent to a $22^{\circ}$ measured from the horizontal. The dimensionless normalized pitch ratio between the period of the blades and the outer radius has an optimal value of 0,2217 for a 3 flight screw.

It is important to determine the flow of water between the screw and the channel in which it is located. Analytical approaches have been developed and represent a complex problem. In spite of that, measurements on built projects have been made and suggest that this flow varies from $2 \%$ to $6 \%$ of the total flow on the screw [7]. For El Chuscal project, a 4\% value is stated.

Geometric specifications meeting the optimization described are summarized in Table 1.

Table 1: $\quad$ El Chuscal screw design values.

\begin{tabular}{|c|c|c|c|}
\hline Inner radius & $\mathrm{R}_{\mathrm{i}}$ & {$[\mathrm{m}]$} & 0.348 \\
\hline Outer radius & $\mathrm{R}_{\mathrm{o}}$ & {$[\mathrm{m}]$} & 0.650 \\
\hline Rotational speed & $\mathrm{n}_{\max }$ & {$[\mathrm{rev} / \mathrm{min}]$} & 42 \\
\hline Radius ratio & $\rho$ & {$[\mathrm{adim}]$} & 0.5357 \\
\hline Screw inclination & $\beta$ & {$\left[{ }^{\circ}\right]$} & 22 \\
\hline Flight pitch & $\Lambda=\mathrm{S}$ & {$[\mathrm{m}]$} & 2.241 \\
\hline$\lambda$ & {$[\mathrm{adim}]$} & 0.2217 \\
\hline Dimensionless normalized pitch & $\mathrm{Vu}$ & {$[\mathrm{adim}]$} & 0.2698 \\
\hline Dimensionless normalized volume per turn & $\lambda * \mathrm{Vu}$ & {$[\mathrm{adim}]$} & 0.0598 \\
\hline Torque generating flow & $\mathrm{Qw}$ & {$\left[\mathrm{m}^{3} / \mathrm{s}\right]$} & 0.583 \\
\hline Number of flights & $\mathrm{N}$ & {$[\mathrm{adim}]$} & 3 \\
\hline Head & $\mathrm{H}$ & {$[\mathrm{m}]$} & 2.800 \\
\hline Screw length & $\mathrm{L}$ & {$[\mathrm{m}]$} & 5.739 \\
\hline Leaking flow percentage & $\% \mathrm{Qg}$ & {$[\mathrm{adim}]$} & $4 \%$ \\
\hline Leaking flow & $\mathrm{Qg}$ & {$\left[\mathrm{m}^{3} / \mathrm{s}\right]$} & 0.024 \\
\hline Power generation flow & $\mathrm{Q}$ & {$\left[\mathrm{m}^{3} / \mathrm{s}\right]$} & 0.607 \\
\hline
\end{tabular}


The screw design allows exploiting the height $2.80 \mathrm{~m}$ difference identified in the field with a $22^{\circ}$ inclination. A scheme of it is displayed in Figure 6.

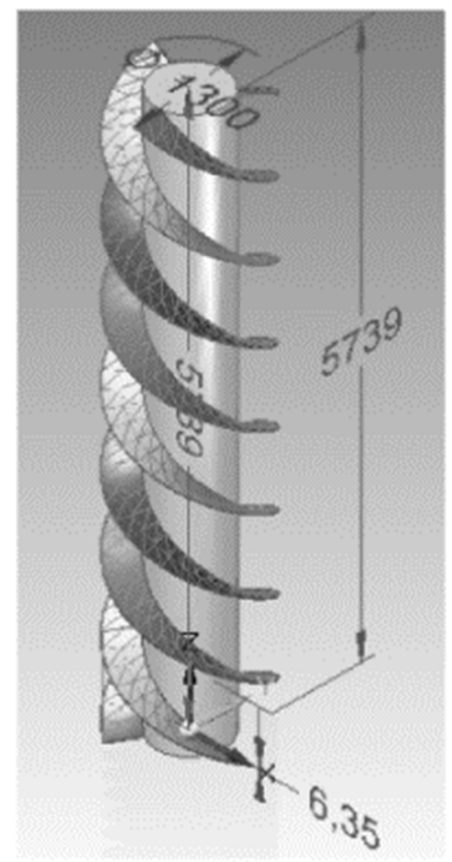

Figure 6: Hydrodynamic screw design scheme. Dimension in mm.

A certain value of efficiency is not determinable, but manufactures of this generation machinery highlight the performance of screws with values higher than $80 \%$. Considering this, and using the site characteristics, the parameters for El Chuscal project are presented below in Table 2. A project with an installed capacity of $13.22 \mathrm{~kW}$ is proposed in the chosen site.

Table 2: Project specifications.

\begin{tabular}{|c|c|c|c|}
\hline Head & $\mathrm{H}_{1}$ & {$[\mathrm{~m}]$} & 2.800 \\
\hline Screw length & $\mathrm{L}$ & {$[\mathrm{m}]$} & 5.739 \\
\hline Efficiency & $\eta$ & {$[\mathrm{adim}]$} & 0.80 \\
\hline Water specific weight & $\gamma$ & {$\left[\mathrm{kN} / \mathrm{m}^{3}\right]$} & 9.81 \\
\hline Flow & $\mathrm{Q}$ & {$\left[\mathrm{m}^{3} / \mathrm{s}\right]$} & 0.607 \\
\hline Power output & $\mathrm{P}$ & {$[\mathrm{kW}]$} & 13.22 \\
\hline
\end{tabular}




\section{Economic analysis}

The location of the project is not close to any electrical substation, this means that the construction of a $13.8 \mathrm{~km}$ transmission line is required in order to achieve connection.

An economical investment analysis was made taking into account the cost of capital, the maintenance cost that may arise and the income flow during an estimated operating life of 30 years. A projection of energy sales was made. Results are presented in Table 3.

Table 3: $\quad$ Total budget of project.

\begin{tabular}{|l|lr|}
\hline \multicolumn{1}{|c|}{ Item } & \multicolumn{2}{c|}{ Cost (USD) } \\
\hline Earth movement & $\$$ & 1,000 \\
\hline $21 \mathrm{MPa}$ concrete & $\$$ & 6,500 \\
\hline Reinforcement steel, fy $=420 \mathrm{MPa}$ & $\$$ & 1,500 \\
\hline Power house & $\$$ & 2,000 \\
\hline Hydrodynamic screw, gearbox and generator* & $\$$ & 58,830 \\
\hline Transmision line & $\$$ & 285,000 \\
\hline Machinery transportation & $\$$ & 2,000 \\
\hline Total & $\$$ & 356,830 \\
\hline
\end{tabular}

*Budget quotation made by Andritz Atro (15 September 2014).

The results were not encouraging; the profit per dollar after 30 years of operation was -0.5 , meaning a loss of 0.5 dollars per each dollar invested.

Even though, several conclusions may be driven from the cost of the project. It is clear how significant is the portion of the transmission line of this generation project. Even though, taking out the cost of the transmission line, and divide this cost by the total output generation an indicative cost of $5433 \$ / \mathrm{kW}$ is found. Although this is twice as expensive as conventional hydro, it is in the range of costs of non-conventional renewables like solar or small-scale wind. This technology could serve alternative would be to use this technology as solutions for non-grid-connected locations next to Andean rivers.

\section{Discussion}

Even though a project might not be feasible under the current market scheme, changes in the regulation might change the game for small renewable technologies.

In 2014, the Colombian Congress passed a new law [8] to promote the participation of non-conventional renewables in the Colombian electric grid. The law includes tax benefits for renewable energy projects and for the import of the electromechanical equipment. Even though these benefits would help the financial 
flows, the game changer for this renewables is that the new law will allow selfgeneration to be directly fed into the distribution grid, with a price bonus to do so. Under this scenario, the prohibitive costs of the transmission lines would be eliminated, having a huge impact in the feasibility of these small hydro alternatives.

The inclusion of demand-response mechanisms and smart grids electric sector may also play beneficial for this type of projects. It is expected that under the new set of rules, domestic renewable energy could be useful to lower the peak demand during daytime, allowing consumer to get additional income. Hydrodynamic screws and other hydro technologies could attend the 24 hour demand, which could prove very useful during the nighttime peak.

Furthermore, the simplicity of and relatively low costs of the hydrodynamic screw could allow small rural Andean communities to invest and sell power to the electric grid, creating new business and development opportunities in vulnerable regions.

\section{References}

[1] Unidad de Planeación Minero Energética, http://www1.upme.gov.co/

[2] Potencial Hidroeléctrico de Antioquia, Inventario, perspectivas y estrategias, BIRD Antioquia, 2011.

[3] Schmalz W. Untersuchungen zum Fischabstieg und Kontrolle möglicher Fischschäden durch die dieWasserkraftschnecke an derWasserkraftanlage Walkmühle an der Werra in Meiningen-Fischökologische und Limnologische Untersuchungsstelle Südthüringen. Rep. 1, Landensanstalt für Umwelt und Geologie, Jena

[4] Lashofer, A., Kaltenberger, F. \& Pelican F. "Wie gut bewährt sich die asserkraftschnecke in der Praxis.” Wasserwirtschaft, 7-8, 76-82, 2011.

[5] Ángel Sanint, E., Mesa Sánchez, Ó. J. \& Rubiano Ortegón, C. Estimación de Caudales Máximos y Mínimos en 162 Cuencas del Oriente Antioqueño. Medellín: Universidad Nacional de Colombia, 1988.

[6] Rorres C. The Turn of the Screw: Optimal Design of an Archimedes Screw. Journal of Hydraulic Engineering, ASCE. pp. 72-80, 2000.

[7] Nuernbergk D. M., Rorres C. Analytical Model for Water inflow of an Archimedes Screw used in Hydropower Generation. Journal of Hydraulic Engineering, ASCE. pp. 213-220, 2013.

[8] Congreso de la República de Colombia. Ley 1715 del 13 de Mayo del 2014. 